\title{
Beneficial Effects of Vitamins, Minerals, and Bioactive Peptides on Strengthening the Immune System Against COVID-19 and the Role of Cow's Milk in the Supply of These Nutrients
}

\author{
M. R. Rezaei Ahvanooei ${ }^{1}$ (D) Mohammad Ali Norouzian ${ }^{1} \cdot$ Payam Vahmani $^{2}$
}

Received: 9 October 2021 / Accepted: 22 November 2021 / Published online: 27 November 2021

(c) The Author(s), under exclusive licence to Springer Science+Business Media, LLC, part of Springer Nature 2021

\begin{abstract}
The COVID-19 pandemic, which causes severe respiratory tract infections in humans, has become a global health concern and is spreading rapidly. At present, the most important issue associated with COVID-19 is the immune system and the factors that affect it. It is well known that cow's milk is highly rich in micronutrients that increase and strengthen the immune system. Research shows that the administration of these nutrients is very effective in fighting COVID-19, and a deficiency in any of them can be a weakness in the fight against the virus. On the other hand, cow's milk is accessible to the whole population, and drinking colostrum, raw, and micro-filtered milk from cows vaccinated against SARS-CoV-2 could provide individuals with short-term protection against the SARS-CoV-2 infection until vaccines become commercially available. This review aimed to discuss the effects of milk vitamins, minerals, and bioactive peptides on general health in humans to combat viral diseases, especially COVID-19, and to what extent cow's milk consumption plays a role in providing these metabolites. Cow's milk contains many bioactive compounds that include vitamins, minerals, biogenic amines, nucleotides, oligosaccharides, organic acids, and immunoglobulins. Humans can meet a significant portion of their requirements for vitamins and minerals through the consumption of cow's milk. Recent studies have shown that micronutrients such as vitamins $\mathrm{D}, \mathrm{E}, \mathrm{B}, \mathrm{C}$, and $\mathrm{A}$ as well as minerals $\mathrm{Zn}, \mathrm{Cu}, \mathrm{Mg}$, I, and Se and bioactive peptides, each can have positive and significant effects on strengthening the immune system and general health in humans.
\end{abstract}

Keywords COVID-19 · Cow milk · Immune system · Mineral · Vitamin

\section{Introduction}

The COVID-19 pandemic has infected and resulted in the death of about 253 and 5.11 million people worldwide, respectively (up to November 14, 2021), and is spreading rapidly. At present, the most important issue associated with COVID-19 is the immune system and the factors that affect it. Therefore, strengthening the immune system in various ways including proper nutrition is a priority.

M. R. Rezaei Ahvanooei

m.rezaei.a@ut.ac.ir

$\triangle$ Mohammad Ali Norouzian

manorouzian@ut.ac.ir

1 Department of Animals and Poultry Science, College of Aburaihan, University of Tehran, Tehran, Iran

2 Department of Animal Science, University of California, 2251 Meyer Hall, Davis, CA 95616, USA
Recently, several studies have examined the effects of heavy metals and their other forms, including nanoparticles, quantum dots, and salts [1] as well as trace elements and electrolytes [2] in patients with COVID-19 and each in turn reported the beneficial effects of these micronutrients on SARS-CoV-2 and its disease, COVID-19. But, the effects of a food such as a cow's milk, which is both widely available and rich in many micronutrients, have been less studied. It has been well established that, vitamins, minerals, and bioactive peptides play an important role in the immune system. Vitamins and minerals are essential components of coenzymes and cofactors, which play an essential role in metabolic reactions. Therefore, disorder or deficiency in the availability of one of these nutrients can lead to metabolic disorders and the subsequent consequence of which is a weakness in the immune system. So, vitamins and minerals should always be present in the body in the required amount. The function of bioactive peptides has also been proven to strengthen the 
immune system and, according to reports, cow's milk contains significant amounts of bioactive peptides [3]. Cow's milk is also rich in vitamins including vitamins $\mathrm{D}, \mathrm{E}, \mathrm{C}, \mathrm{B}$, and $\mathrm{A}$ [4], and minerals including $\mathrm{Zn}, \mathrm{Cu}$, $\mathrm{Mg}$, I, and $\mathrm{Se}[4,5]$. Research shows that each of these nutrients is very effective in fighting COVID-19, and a deficiency in any of them can be a weakness in the fight against the virus. For example, vitamin D has been recognized as a potential strategy for the prevention or treatment of COVID-19 [6]. Recently, several studies have shown a potential link between vitamin D deficiency and susceptibility to various diseases, including systemic infections $[7,8]$. Using vitamin D supplement has been shown to reduce viral respiratory infections, especially in people with vitamin D deficiency [9]. Vitamin D increases innate immunity by increasing the secretion of antiviral peptides $[10,11]$. Therefore, its deficiency may suppress immune function, which increases the risk of COVID19 and mortality [6]. Vitamin $\mathrm{C}$ also has an antioxidant effect due to its ability to donate electrons and thus protect molecules against oxidative damage. In addition, vitamin $\mathrm{C}$ plays an essential role in the function and regulation of the immune system [12]. It also activates the caspasedependent cascade, which causes programmed apoptosis and necrosis [13]. Other effects of vitamin $\mathrm{C}$ in regulating inflammation include modulating the nuclear transcription factor kappa $\mathrm{B}(\mathrm{NF \kappa B})$ and reducing the production of inflammatory cytokines [14]. Therefore, its deficiency may weaken the immune system and increase the risk of COVID-19. According to studies, vitamin E increased and strengthened the immune system in human and animal models through several mechanisms [15]. Vitamin E affects the immune system through protein kinase $\mathrm{C}$ (PKC) and modulates it. PKC inhibition has been shown to affect the proliferation of monocytes, macrophages, neutrophils, and smooth muscle cells, and reduce the production of superoxide free radicals in neutrophils and macrophages [16]. Thus, vitamin E plays an important role in the normal functioning of the immune system and a sufficient amount of it is needed in the body to fight COVID-19. B vitamins also play an essential role in the proper functioning of the cell, energy metabolism, and the proper functioning of the immune system [17]. Vitamin B deficiency can significantly impair the function of cells and the immune system and lead to the inflammation caused by hyperhomocysteinemia [18]. Therefore, vitamin B can be used as a nonpharmacological supplement to treat COVID-19. Vitamin $\mathrm{A}$ is also known as an anti-inflammatory vitamin because of its vital role in boosting immune function. Vitamin A is involved in the development of the immune system, has a regulatory role in cellular immune regulation and humoral immune processes, and its use has been shown to have a therapeutic effect in the treatment of various infectious diseases [19]. Therefore, vitamin A can also be an effective factor in combating COVID-19.

Minerals, as mentioned, also play an important role in the proper functioning of the immune system and the fight against COVID-19. In vitro studies have shown that Zinc (Zn) induces Interferon-alpha (IFN- $\alpha$ ) and gamma (IFN- $\gamma$ ) production and can enhance the antiviral function of the former [20]. Zn-induced changes in capillary epithelium may inhibit transcapillary motility of plasma proteins and reduce local edema, inflammation, and mucosal secretion [21]. Finally, $\mathrm{Zn}$ can protect or stabilize the cell membrane that is involved in inhibiting the virus from entering the cell [22]. According to one study, copper $(\mathrm{Cu})$ exposure to human coronavirus $229 \mathrm{E}$ destroyed the viral genomes and irreversibly affected the morphology of the virus [23]. $\mathrm{Cu}$ ions can damage viral genomic DNA by binding and crosslinking between and within genome strands [24]. Therefore, $\mathrm{Cu}$ can also be introduced as an effective element in combating COVID-19. Magnesium (Mg) has a known "calciumchannel blocking" effect. This mineral can inhibit calcium $\left(\mathrm{Ca}^{+2}\right)$ influx in immunocompetent cells, which limits nuclear factor jB (NF-jB) activation, cytokine production, and resulting systemic inflammation [25, 26]. Iodine (I) is an essential trace element for humans and animals and its deficiency can affect basal metabolism and immune system function [27, 28]. Studies have also shown the unique properties of iodine germicide [29]. People with I deficiency, in large numbers around the world, suffer from physical illnesses and weakened immune systems [30]. Therefore, these people are highly susceptible to COVID-19. According to studies, selenium $(\mathrm{Se})$ has also been introduced as a positive modulator of the immune system [31], which can be considered an important element in the fight against COVID-19.

The main purpose of this study was to investigate the effects of vitamins, minerals, and bioactive peptides on general health in humans to combat viral diseases, especially COVID-19, and to what extent cow's milk consumption plays a role in providing these metabolites.

\section{Method}

The bibliographic search was performed on Scopus, PubMed, and Google scholar databases in May 2021. Search keywords including "Mineral," "Zinc" or "Zn," "Copper" or "Cu," "Magnesium" or "Mg," "Iodine" or "I," "Selenium" or "Se," "Vitamin D," "Vitamin C" or "Ascorbic acid," "Vitamin E" or "Tocopherol," "Vitamin B1" or "Thiamine," "Vitamin B2" or "Riboflavin," "Vitamin B3" or "Niacin," "Vitamin B5" or "Pantothenic acid," "Vitamin B6" or "Pyridoxine," "Vitamin B7" or "Biotin," "Vitamin B9" or "Folic acid," "Vitamin B12" or "Cobalamin," "Vitamin A" or "Retinoic acid," "Bioactive peptide," "Cow milk," 
"Immune system" and "coronavirus 2019" or "COVID-19" or "SARSCoV-2" in all fields. Any languages or date restrictions were not applied. Identified studies were screened by title, abstract, and full text. Then, according to the screening performed among the selected articles, those that did not meet the criteria for use in the study were removed. The remaining articles were entered into the database and collected using Endnote software. Secondary screening (based on title, abstract, and full-text review) was performed to accurately match the selected articles in relation to the subject under study and finally, usable articles in this study were selected. During the article writing process, a new update of each database was screened to consider any newly published article suitable to include in the review process.

\section{The Content of Vitamins and Minerals in Cow's Milk and Requirements in Humans}

In terms of macronutrients, cow's milk is generally composed of water (85-87\%), fat (3.8-5.5\%), protein (2.9-3.5\%) and carbohydrates (5\%). But in terms of micronutrients, it contains many bioactive compounds that include vitamins, minerals, biogenic amines, nucleotides, oligosaccharides, organic acids, and immunoglobulins [32]. Humans can meet a significant portion of their requirements for vitamins and minerals through the consumption of cow's milk. The amount of these metabolites in raw cow's milk (with 3\% fat) as well as the recommended daily intake is shown in Tables 1 and 2 .

\section{The Effect of Vitamins Against COVID-19}

\section{Vitamin D}

Vitamin D is a steroid hormone that is produced endogenously by the effects of ultraviolet light on the skin or is available from outside food sources or supplements. Recently, a meta-analysis was performed on the effectiveness of vitamin D supplementation in preventing acute respiratory infections (ARIs). Based on the results of 25 randomized controlled trials (RCTs) in which complete data of approximately 11,000 individual patients were available, subgroup analysis showed that this advantage is seen in individuals who receive repeated doses (e.g., daily) of vitamin $D$ receive (and not in those receiving bolus doses). And the greatest effect is when vitamin $\mathrm{D}$ is given to people who are deficient in vitamin D [9]. Another study found that vitamin D stimulates innate immunity and modulates acquired immunity [35], which may be a reason for the meta-analysis results. Vitamin D deficiency is common and is more in people with darker skin, obesity, old age, or less exposure to the sun [36, 37]. Therefore, people who are at risk for vitamin D deficiency, especially during the COVID-19 epidemic, should take vitamin D supplements to maintain optimal blood circulation (75-125 nmol/L) [38]. Recent studies suggest that there is a similar association between raw cow's milk intake and respiratory infections. According to a study, vitamin D in cow's milk can affect the homing of lymphocytes to the upper respiratory tract by expression of the tissue homing-associated markers CCR9 or CCR10 on lymphocytes in humans [39]. In relation to nursing infants, cow's milk contains similar concentrations of vitamin D3 and 1,25 $(\mathrm{OH})$ vitamin $\mathrm{D}_{3}$ (the active form of vitamin $\mathrm{D}_{3}$ ) compared to breast milk and can cause the same desired effect [40]. In addition, recent reports, which specifically discuss COVID-19, have shown that vitamin D increases anti-inflammatory cytokines [41] inhibits the accumulation of proinflammatory cytokines and induces defensins and cathelicidins prevents the replication of viruses [6], thereby potentially reducing the recovery time of patients with viral infections, particularly COVID-19 [42]. Therefore, vitamin D in cow's milk can be introduced as an important metabolite against respiratory diseases. Finally, given that COVID-19 directly targets the immune and respiratory systems, it seems that taking vitamin D supplements, especially in those with vitamin D deficiency, can be an effective step against COVID-19. According to the results of the analysis of compounds, cow's milk contains a significant amount of vitamin $\mathrm{D}(0.0167 \mathrm{mg} / \mathrm{L})$ and according to the needs of vitamin $\mathrm{D}$ in humans (Table 1), consumption of 2 glasses of milk per day (about $350 \mathrm{~mL}$ ) can meet all the needs of all age groups.

\section{Vitamin C}

Vitamin C (ascorbic acid) is a water-soluble vitamin that plays an important role as an antioxidant and as a correlation factor of various biosynthetic pathways in the immune system. It is an essential nutrient that cannot be synthesized by the human body [43]. Vitamin $\mathrm{C}$ has numerous positive effects on the immune system [14, 44]. In a metaanalysis of 29 controlled trials with 11,306 participants, it was shown that regular intake of about $1 \mathrm{~g}$ of vitamin $\mathrm{C}$ per day did not prevent upper respiratory tract infection (URTI). However, the same experiments showed that vitamin $\mathrm{C}$ shortened and reduced URTIs (reducing the duration of infection by $8 \%$ in adults and $14 \%$ in children) during the course of vitamin $\mathrm{C}$ administration [45]. Based on the above results, and given that COVID-19 is often much more severe than normal URTIs, and while COVID19 is highly prevalent, a regular increase in daily vitamin $\mathrm{C}$ intake may be justifiable. Experimental results show that serum and leukocyte levels of vitamin $\mathrm{C}$ decrease in 
Table 1 The amount of different vitamins in raw cow's milk (with 3\% fat) and human requirements

\begin{tabular}{|c|c|c|c|c|c|c|c|}
\hline \multirow[t]{2}{*}{ Vitamins } & \multirow{2}{*}{$\begin{array}{l}\text { Amount in cow's milk } \\
\text { (with } 3 \% \text { fat) }(\mathrm{mg} / \mathrm{L})[4]\end{array}$} & \multicolumn{3}{|c|}{ Human requirements (mg/day) [33] } & \multicolumn{3}{|c|}{$\%$ of requirements $*$} \\
\hline & & $1-9$ years & $10-18$ years $^{\mathrm{a}}$ & $19-65$ years $^{\mathrm{a}}$ & $1-9$ years & $10-18$ years $^{\mathrm{a}}$ & $19-65$ years $^{\mathrm{a}}$ \\
\hline $\mathrm{D}$ & 0.0167 & 0.005 & 0.005 & $0.005-0.01$ & 100 & 100 & $100-50$ \\
\hline $\mathrm{B}_{1}$ & $0.47 \pm 0.026$ & $0.5-0.9$ & $1.1 / 1.2$ & $1.1 / 1.2$ & $32-18$ & $15 / 13.5$ & $15 / 13.5$ \\
\hline $\mathrm{B}_{2}$ & $2.37 \pm 0.037$ & $0.5-0.9$ & $1.0 / 1.3$ & $1.1 / 1.3$ & $165-92$ & $82 / 63$ & $75 / 63$ \\
\hline $\mathrm{B}_{3}$ & $1.391 \pm 0.02$ & $6-12$ & 16 & $14 / 16$ & $8-4$ & 3 & $3.5 / 3$ \\
\hline $\mathrm{B}_{5}$ & $4.384 \pm 0.21$ & $2-4$ & 5 & 5 & $76-38$ & 30 & 30 \\
\hline $\mathrm{B}_{6}$ & $0.304 \pm 0.016$ & $0.5-1.0$ & $1.2 / 1.3$ & $1.3-1.6$ & $21-10.5$ & $9 / 8$ & $8-6.5$ \\
\hline $\mathrm{B}_{7}$ & 0.021 & $0.008-0.02$ & 0.025 & 0.03 & $91-35$ & 29 & 23 \\
\hline $\mathrm{B}_{9}$ & 0.039 & $0.15-0.3$ & 0.4 & 0.4 & $8.5-4$ & 3 & 3 \\
\hline $\mathrm{B}_{12}$ & $0.005 \pm 0.0001$ & $0.0009-0.0018$ & 0.0024 & 0.0024 & 194-97 & 73 & 73 \\
\hline $\mathrm{E}$ & $0.387 \pm 0.086$ & $12-15$ & $12-15$ & $12-15$ & $1.1-0.9$ & $1.1-0.9$ & $1.1-0.9$ \\
\hline $\mathrm{C}$ & $5.98 \pm 0.052$ & $30-35$ & 40 & 45 & $7-6$ & 5 & 4.5 \\
\hline $\mathrm{A}$ & $0.156 \pm 0.002$ & $0.2-0.25$ & $0.33-0.4$ & $0.27 / 0.3$ & $27-22$ & $16.5-13.5$ & $20 / 18$ \\
\hline
\end{tabular}

*According to its amount in raw milk with $3 \%$ fat and based on consuming 1.5 cups of milk (350 mL) per day

${ }^{\mathrm{a}}$ The first number is for females/the second number is for males

the acute phase of infection [46, 47]. Therefore, this deficiency must be compensated for the proper functioning of the immune system. According to the observations, one of the most important problems related to COVID-19 is the relatively large number of patients who need treatment with an intensive care unit (ICU). In this regard, a meta-analysis of 12 experiments with 1766 patients in the ICU showed that vitamin $\mathrm{C}$ reduces the length of stay of patients in the ICU by $8 \%$ [48]. Numerous results from various studies introduce vitamin $\mathrm{C}$ as a powerful antioxidant and are said to have a modulating effect on the immune system $[49,50]$. Vitamin $\mathrm{C}$ protects molecules from oxidative damage due to its ability to donate electrons, thereby exerting its antioxidant effect. The antioxidant properties and scavenging ability of vitamin $\mathrm{C}$ have made it a protector of neutrophils and phagocytes against damage caused by oxidative bursts. Vitamin $\mathrm{C}$ also activates the caspase-dependent cascade, which increases apoptosis is programmed and inhibits necrosis $[13,51]$. Other positive effects of vitamin $C$ in regulating inflammation include modulating the NFKB and reducing the production of inflammatory cytokines [14]. According to the results mentioned of vitamin $\mathrm{C}$ in connection with the immune system, it seems that the supply of it to the extent necessary to combat the adverse effects of COVID-19 is inevitable. One of the dietary sources of vitamin $\mathrm{C}$ is cow's milk. According to reports, the amount of vitamin C in cow's milk is very low $[4,52]$ and according to its requirements in humans, as mentioned in Table 1 (30 to $45 \mathrm{mg}$ per day/person), cannot be expected to get enough vitamin $\mathrm{C}$ for every person by consuming cow's milk. So, although cow's milk does not meet all of human vitamin $\mathrm{C}$ needs, it can be beneficial when viewed in conjunction with the effects of other components of cow's milk that strengthens the immune system. In any case, based on the results, cow's milk contains $5.98 \mathrm{mg} / \mathrm{L}$ of vitamin $\mathrm{C}$, and according to the needs listed in Table 1, consuming $350 \mathrm{~mL}$ of milk per day can meet only about $5-7 \%$ of the needs of different age groups.

Table 2 The amount of different minerals in raw cow's milk (with 3\% fat) and human requirements

\begin{tabular}{|c|c|c|c|c|c|c|c|}
\hline \multirow[t]{2}{*}{ Minerals } & \multirow{2}{*}{$\begin{array}{l}\text { Amount in cow's milk } \\
\text { (with 3\% fat) (mg/L) [4] }\end{array}$} & \multicolumn{3}{|c|}{ Human requirements (mg/day) [33] } & \multicolumn{3}{|c|}{$\%$ of requirements $*$} \\
\hline & & $1-9$ years & $10-18$ years $^{\mathrm{a}}$ & $19-65$ years $^{\mathrm{a}}$ & $1-9$ years & $10-18$ years $^{\mathrm{a}}$ & $19-65$ years $^{\mathrm{a}}$ \\
\hline $\mathrm{Zn}$ & $4.511 \pm 0.392$ & $2.76-3.72$ & $8.33 / 6.12$ & $3.24 / 4.68$ & $57-42$ & $19 / 25.5$ & $48.5 / 33.5$ \\
\hline $\mathrm{Cu}$ & $0.082 \pm 0.006$ & $0.4-0.7$ & $0.8-1$ & 1.2 & $7-4$ & $3.5-3$ & 2.5 \\
\hline $\mathrm{Mg}$ & $105.11 \pm 11.49$ & $60-100$ & $220 / 230$ & $220 / 260$ & $61-36.5$ & $16.5 / 16$ & $16.5 / 14$ \\
\hline I [34] & $0.284 \pm 0.055$ & $0.09-0.12$ & 0.15 & 0.15 & $110-83$ & 66 & 66 \\
\hline $\mathrm{Se}$ & $0.028 \pm 0.002$ & $0.017-0.021$ & $0.026 / 0.032$ & $0.026 / 0.034$ & $57.5-46.5$ & $37.5 / 30.5$ & $37.5 / 29$ \\
\hline
\end{tabular}

*According to its amount in raw milk with $3 \%$ fat and based on consuming 1.5 cups of milk $(350 \mathrm{~mL})$ per day

${ }^{a}$ The first number is for females/the second number is for males 


\section{Vitamin E}

Vitamin $\mathrm{E}$ is a fat-soluble compound, which consists of eight isoforms, four tocopherols ( $\alpha-, \beta-, \gamma$, and $\delta$-tocopherols), and four tocotrienols ( $\alpha-, \beta-, \gamma-$, and $\delta$-tocotrienols), and it is a lipid component of biological membranes. The various isoforms in the human body are not interchangeable, and of these, only $\alpha$-tocopherol meets the human needs for vitamin E. Vitamin $\mathrm{E}$ has a powerful antioxidant role and is able to neutralize free radicals and reactive oxygen species (ROS) by donating hydrogen ions from its chromanol ring. If ROS is released, it leads to lipid peroxidation in the cell membrane, which in turn increases permeability and destroys cell membrane integrity. Oxidative stress is one of the driving pathological mechanisms that underpins the biology of acute respiratory distress syndrome (ARDS) as a result of COVID-19. According to the findings, vitamin $\mathrm{E}$ increases the immune response in animal and human models through the following three mechanisms: (1) decreased production of nitrogen oxide resulting in prostaglandin E2 downregulation and inhibition of cyclooxygenase-2, (2) initiation of T lymphocyte signals, and (3) modulation of the Th1/Th2 balance [15]. Another immune-modulating effect of vitamin $\mathrm{E}$ occurs through protein kinase $\mathrm{C}$ (PKC). Inhibiting PKC has been shown to affect the proliferation of monocytes, macrophages, neutrophils, and smooth muscle cells, and reduce superoxide free radical production in neutrophils and macrophages [16]. The term immunosenescence refers to the gradual decline of the immune system with age. Vitamin E has been illustrated to enhance $\mathrm{T}$ lymphocyte-mediated immune function in response to mitogens and IL-2 but also neutrophil and natural killer function, the decline of which is seen with increasing age $[53,54]$. Therefore, considering the said effects of vitamin $\mathrm{E}$ in strengthening the immune system, it can be used as an effective agent against COVID19. According to studies on the composition of milk, cow's milk contains very low amounts of vitamin E $(0.387 \mathrm{mg} / \mathrm{L})$ relative to human needs. Therefore, considering the human need for vitamin $\mathrm{E}$, consuming $350 \mathrm{~mL}$ of milk per day can provide only about $1 \%$ of the needs of all age groups. Therefore, despite the positive effects of vitamin $E$ on strengthening the immune system, cow's milk cannot be a good supplier of this desired effect, but from a synergistic perspective of milk compounds, in order to improve immune function, although small, can be effective.

\section{Vitamin B}

$B$ vitamins are a group of water-soluble vitamins $\left(B_{1}, B_{2}, B_{3}\right.$, $\mathrm{B}_{5}, \mathrm{~B}_{6}, \mathrm{~B}_{7}, \mathrm{~B}_{9}$, and $\mathrm{B}_{12}$ ), each of which can play an essential role in cell metabolism. According to the analysis performed, cow's milk contains all the B vitamins, of which $\mathrm{B}_{5}, \mathrm{~B}_{3}$, and $\mathrm{B}_{2}$ have the highest concentrations, respectively
[4]. Dietary supplements that contain all eight B vitamins are called B-complex. Reports show that B-complex supplements may regulate cytokine/chemokine generation and mediate interaction with immune cells involved in inflammation and pathophysiological pathways [55]. Vitamin $\mathrm{B}_{1}$ (thiamine), like other B-complex vitamins, acts as a coenzyme in phosphorylated forms and is involved in the metabolism of fats, glucose, as well as protein, and consequently plays a key role in energy production in the body. Its deficiency in the nervous system may impair the ability to synthesize fatty acid and cholesterol, necessary for membrane function. With particular attention to inflammation, vitamin B1 deficiency in the brain causes overexpression of proinflammatory mediators such as IL-1, IL-6, COX-2, and TNF- $\alpha$, which in turn causes the death of neuronal cells in the central nervous system (CNS), damage, and neuroinflammation that eventually leads to Wernicke's encephalopathy and irreversible dementia of Korsakoff's syndrome [56]. The previous results show that thiamine can improve the function of the immune system in the body and is also able to reduce disorders caused by neurodegenerative [17]. Thiamine deficiency can lead to a number of disorders in the body, including effects on the functioning of the cardiovascular system, increased neuroinflammation, and inflammation, which ultimately leads to improper antibody responses [17]. Because antibodies, and most importantly $\mathrm{T}$ cells, are required to kill COVID-19, thiamine deficiency can potentially lead to weak antibody responses, resulting in more severe symptoms. Vitamin $\mathrm{B}_{2}$ (riboflavin) has immunomodulatory effects, and deficiency upregulates proinflammatory gene expression [55]. According to the reported results, riboflavin and UV light were effective against the MERS-CoV virus, and this result indicates that riboflavin can also have beneficial effects against SARS-CoV-2 [57]. Riboflavin in combination with UV light causes irreversible damage to nucleic acids (such as DNA and RNA) and thus prevents the proliferation of microbial pathogens. Niacin, an amide of $B_{3}$, reduces TNF- $\alpha$, IL- 6 , and IL-1 $\beta$ in stimulated alveolar macrophages and inhibits NFKB activation [58]. The results of new studies show that special attention to IL- 6 can lead to the control of inflammatory storms in patients with COVID-19 [59]. Niacin is an essential substance in the synthesis of NAD and NADP, both of which are vital during chronic systemic inflammation [60]. According to Janet et al. in 2012, niacin has substantial anti-inflammatory effects in human monocytes [61]. Considering the protective role and strengthening of lung immunity by niacin, it can be used as adjunctive therapy for COVID-19 patients $[62,63]$. Pantothenic acid $\left(\mathrm{B}_{5}\right)$ also has a number of anti-inflammatory functions and improves mental health [17]. Pyridoxal 5'-phosphate (PLP) is an active form of $B_{6}$ (pyridoxine) and a major factor in various inflammatory pathways, and its deficiency leads to immune system disorders. A recent study suggested that PLP supplementation 
reduced the adverse effects and symptoms of COVID-19 by regulating immune responses, reducing proinflammatory cytokines, maintaining endothelial integrity, and preventing excessive coagulation [64]. Therefore, it may be that PLP can help reduce cytokine storms and inflammation suffered by some COVID-19 patients. Vitamin $B_{7}$ (biotin) also affects the expression of proinflammatory cytokines and is considered a vitamin that regulates the immune system [65]. One study suggested that folic acid $\left(\mathrm{B}_{9}\right)$ could be useful for the management of COVID-19-related respiratory disease in its early stages [66]. Vitamin B9 has been shown to have a potential binding affinity to the SARS-CoV-2 protease [67]. Therefore, the use of folic acid can be considered a useful treatment for the management and control of COVID19 [68]. It has been shown that $B_{12}$ (cobalamin) deficiency can lead to disorders of the respiratory system, gastrointestinal tract, and central nervous system [69]. Like vitamin $\mathrm{B}_{9}$, vitamin $\mathrm{B}_{12}$ has been shown to have a potential binding affinity to the SARS-CoV-2 protease [70]. A recent study also showed that methylcobalamin supplements have the potential to reduce the harm and symptoms associated with COVID-19 [71]. Based on composition analysis, in terms of supply of B vitamins to humans by cow's milk, vitamins $B_{2}$ and $B_{12}$ had the highest share and vitamins $B_{3}$ and $B_{9}$ had the lowest share and the rest were in the middle of them (Table 1). However, at a glance, we can say that cow's milk is relatively successful in providing B vitamins for humans, and it seems that consuming $350 \mathrm{~mL}$ of it per day can show the positive effects of B vitamins on the immune system.

\section{Vitamin A}

Vitamin A is in the category of fat-soluble vitamins and its presence in the body is essential for the normal functioning of vision, growth and development, and the protection of epithelial tissue and mucosal integrity [19]. Vitamin A plays an important role in modulating the immune system [19]. According to the results, vitamin A not only proliferates $\mathrm{T}$ lymphocytes (by increasing IL-2) but also enhances their differentiation, especially in regulatory $\mathrm{T}$ cells. Reports indicate that vitamin $\mathrm{A}$ has been used as a supplement to improve antibody response when used in vaccines such as tetanus, diphtheria, measles, influenza, rabies, and malaria in infants [72, 73]. According to the results of an experiment, vitamin A and D supplements increased humoral immunity in pediatric patients after influenza vaccination [74]. The results of a study show that vitamin A supplementation improves pulmonary function test results in patients with chronic obstructive pulmonary disease (COPD) [75]. Retinol deficiency has been shown to cause squamous metaplasia, the first barrier to respiratory defense, the epithelium [76]. It has been demonstrated that vitamin A has antioxidant properties and plays an essential role in the development of bronchopulmonary dysplasia and neonatal respiratory distress syndrome [77, 78]. Recently, a report evaluated the role of retinoic acid in patients with COVID-19. According to the results of this study, retinoic acid depletion can change the position of the immune system to the NFKB arm, which in turn leads to excessive release of cytokines, and thus by creating a cytokine storm, conditions provided for the occurrence of inflammatory diseases, especially COVID-19 and ARDS [79]. According to a study, vitamin A in cow's milk also can affect the homing of lymphocytes to the upper respiratory tract by expression of the tissue homing-associated marker $\alpha 4 \beta 7$ on lymphocytes in humans [39]. A study in the USA and Canada found that vitamin A in cow's milk plays a key role in cell differentiation and immunity [80]. Finally, vitamin A may play an important role in the fight against viral diseases, including COVID-19, by having pulmonary, immunomodulatory, and antimicrobial roles [81]. According to the report in Table 1, cow's milk contains $0.156 \mathrm{mg} / \mathrm{L}$ of vitamin A. Given the amount of vitamin A needed in humans, consuming $350 \mathrm{~mL}$ of cow's milk per day can meet 20-27\% of the needs of different age groups. This percentage of vitamin A supply through milk consumption can be considered and also convince us that the positive and significant effects of vitamin A on immune function can be observed through the consumption of cow's milk (Fig. 1).

\section{The Effect of Minerals Against COVID-19}

\section{Zinc}

Zinc $(\mathrm{Zn})$ is a mineral required in several processes in the cell and has several direct and indirect antiviral effects that are realized through various mechanisms. Zn supplementation enhances antiviral, intrinsic, and humoral immunity, and restores the function of immune cells or improves the function of normal immune cells, especially in immunocompromised or elderly patients [82]. Specifically, $\mathrm{Zn}^{2+}$ was shown to inhibit polyprotein processing in cells infected with human rhinovirus and coxsackievirus B3 [83]. The immune response led by interferons (IFN) and cytotoxic T lymphocytes is invariably required to clear viral infections [82]. Adequate $\mathrm{Zn}$ is essential for the proper functioning and proliferation of neutrophils, macrophages, $\mathrm{T}$ and $\mathrm{B}$ lymphocytes, and NK cells, and can also control the production of cytokines by immune cells. Other effects of $\mathrm{Zn}$ include its protective role against the harmful effects of ROS, which are mainly produced during inflammatory processes [84]. According to the findings, $\mathrm{Zn}$ deficiency reduces the production of antibodies, affects the function of the innate immune system, reduces the production of cytokines by monocytes, and also causes chemotaxis and oxidative explosion of neutrophil granulocytes [20]. Zn can suppress the inflammatory 


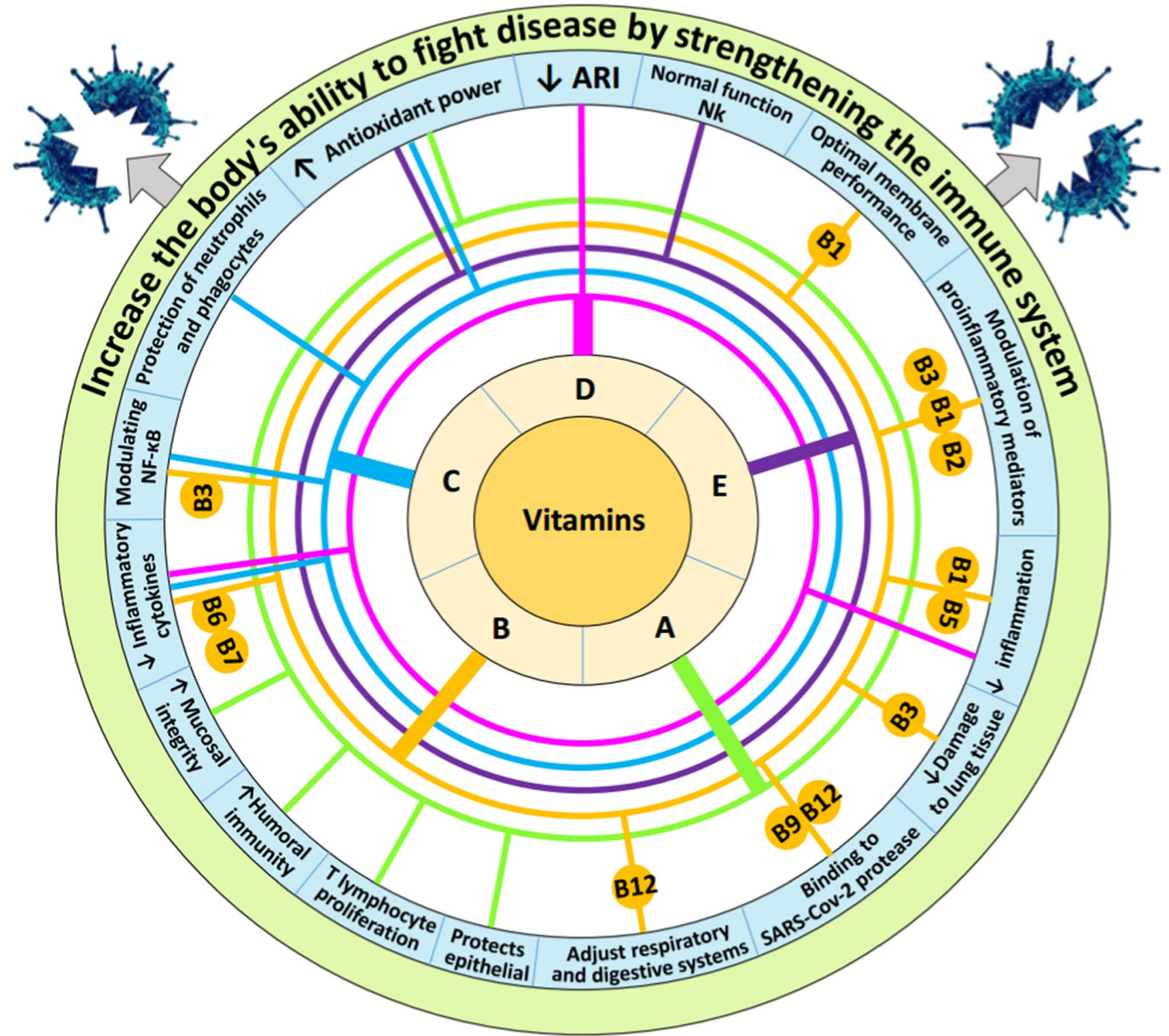

Fig. 1 Important effects of vitamins on strengthening the immune system and resistance to pathogens

response by affecting the secretion of proinflammatory cytokines and monocyte signal transduction, as well as interfering with the binding of leukocyte function-associated antigen-1 to ICAM-1 [85]. It has been suggested that $\mathrm{Zn}$ may have a protective role on cell membranes or stabilized it, thereby preventing the virus from entering the cell [22]. According to a recent study, the effects of $\mathrm{Zn}$ may be synergistic if used concomitantly with standard antiviral therapy [86]. The results of a study show that $\mathrm{Zn}$ effectively inhibits the RNA-synthesizing activity of nidoviruses (including SARS-CoV) in vitro, which is realized through alteration of RNA-dependent RNA polymerase (RdRp) activity during the elongation phase of RNA synthesis, probably by directly affecting template binding [87]. Finally, this suggests that
$\mathrm{Zn}$ supplementation may be useful for the prevention and treatment of COVID-19. Based on the results of the analysis of compounds, cow's milk contains a significant amount of zinc $(511.4 \mathrm{mg} / \mathrm{L})$ and according to the need for zinc in humans, consumption of $350 \mathrm{~mL}$ of cow's milk per day can meet about $19-57 \%$ of the needs of different ages groups (Table 2). Therefore, it seems that the positive effects of $\mathrm{Zn}$ on the immune system and disease resistance can be seen significantly with the consumption of cow's milk.

\section{Copper}

Copper $(\mathrm{Cu})$ is an essential trace element for humans [88]. $\mathrm{Cu}$ is required for the normal functioning of critical 
immune cells such as B cells, helper T cells, neutrophils, macrophages, and natural killer (NK) cells [89]. Dietary $\mathrm{Cu}$ is absorbed in the small intestine and quickly enters the bloodstream. The antimicrobial properties of $\mathrm{Cu}$ have been well established, and according to the results of in vitro studies, coronaviruses exposed to copper do not survive for a long time [90, 91]. Copper plays an essential role in respiration, immune function, and free radical defense [92]. When oxidative stress occurs, enzymes that contain copper in their structure perform important functions such as $\mathrm{O}_{2}$ transport, metabolism, and the production of signaling molecules. Enzymes such as CuZn-superoxide dismutase, which play a major role in defending against oxidative stress, contain copper in their structure [93]. According to a report, the coronavirus (SARS-CoV-2), responsible for the current epidemic of COVID-19, is highly sensitive to copper levels [90]. Copper exposure to human coronavirus $229 \mathrm{E}$ destroyed the viral genomes and irreversibly affected virus morphology, including disintegration of envelope and dispersal of surface spikes [23]. Therefore, due to its strong antiviral activity, copper may also act as a prevention and treatment regimen against COVID-19 [89]. As can be seen from Table 2, relative to human requirements, cow's milk contains a small amount of copper $(0.082 \mathrm{mg} / \mathrm{L})$. Therefore, consuming $350 \mathrm{~mL}$ of cow's milk per day can provide only 2 to $7 \%$ of the copper needed in all age groups. Accordingly, it is not possible to observe the significant beneficial effects of only copper on the immune system through milk consumption. But with an overview and look at these metabolites as a package, the role and contribution of each in achieving the ultimate goal can be significant.

\section{Magnesium}

Magnesium $(\mathrm{Mg})$ as an enzymatic activator is essential for various physiological functions such as cell cycle, metabolic regulation, muscle contraction, and vasomotor tone [94]. $\mathrm{Mg}$ plays a role in shaping innate and adaptive immune systems [95]. Two unique characteristics observed in patients with COVID-19 are specifically related to magnesium nutrition and warrant further investigation, including (1) cytokine storm, which represents an increase in IL-6 and C-reactive protein and (2) hypokalemia [96]. A wealth of evidence suggests that magnesium supplementation prevents or treats a variety of disorders or diseases related to the respiratory system, nervous system, gastrointestinal tract, and cancer [94]. A low Mg status activates inflammation, by sensitizing sentinel cells to the noxious agent, priming phagocytes, and participating in the orchestration of the vascular and cellular events that characterize the process [97]. Evidence has been provided that $\mathrm{Mg}$ concentration in acutely inflamed tissues is reduced through the activation of the IL-33/ST2 axis [98]. Based on the results, it is hypothesized that subclinical magnesium deficiency exacerbates viral inflammation. It therefore causes uncontrolled secretion of high levels of proinflammatory cytokines, and the end result is a storm of cytokines, which can be fatal [99]. In support of our findings, some studies have also suggested that trace elements such as magnesium, vitamins, and other nutrients play an important and complementary role in supporting the immune system and fighting COVID-19 [31, 100]. Finally, based on the reports and the role of magnesium in improving the function of the immune system and reducing inflammation, it can be said that one of the most important factors in combating COVID-19 is the optimal level of magnesium in the body. Figures related to magnesium in Table 2 show that cow's milk contains a significant amount of magnesium $(105.11 \mathrm{mg} / \mathrm{L})$ and according to its needs in humans, consumption of $350 \mathrm{~mL}$ of cow's milk per day can provide $14-61 \%$ of the needs of different age groups. Therefore, it can be said that the beneficial effects of magnesium on the immune system and general health can be significantly observed through milk consumption, especially in children.

\section{lodine}

Iodine (I) is an essential trace element for humans and animals and its deficiency can affect basal metabolism and immune system function [27, 28]. People with I deficiency, in large numbers around the world, suffer from physical illnesses and weakened immune systems [30]. Iodine deficiency is considered by the World Health Organization (WHO) and the United Nations Children's Fund as one of the most important nutritional factors that have a decisive impact on the health status of the population, especially children at all stages of their development [101]. Disruption of the acute phase response to infections as well as the function of cytokines is a consequence of the suppression of the immune system, which in turn negatively affects the natural history of inflammatory diseases [102]. The results of a study show that iodine treatment in newborn lambs with a respiratory syncytial virus (RSV) results in less lung damage and less pulmonary expression of RSV antigen. Iodine supplementation in 3-week-old lambs also reduced the severity of RSV infection, according to the results [103]. According to a report in 2015, iodine is an effective and useful germicide and it has beneficial effects against a variety of microorganisms such as viruses [104]. In addition, according to other reports, Tasco-Forage, an extract of the iodine-rich brown seaweed Ascophyllum nodosum, increased antioxidant activity and further strengthened the immune system in pasture animals $[105,106]$.

The results of an in vitro study showed that iodine use could increase the synthesis of immunoglobulin-G in human lymphocytes [107]. Another study showed that iodide has an immunomodulatory effect on human peripheral 
blood immune cells. According to the report, providing the required level of iodine induces stronger cytokine and chemokine responses, strengthens the immune system, and helps clear infections [108]. Pathophysiological research also shows that iodine can support the innate immune system in fighting bacterial and viral infections [103]. According to reports, Japanese people consume more iodine than other countries, and according to statistics, a much lower percentage of COVID-19 virus prevalence and deaths in this country than in other countries, according to high population density is observed in this country [109, 110]. Therefore, due to the fact that iodine has very limited side effects and rapid absorption and is also reported to be an effective element in strengthening the immune system, it can be used as a low-cost and available golden solution to optimal prevention and treatment of COVID-19.

Iodine needs are met through the consumption of iodinecontaining foods. In the past, the side effects of iodine deficiency (goiter, mental retardation, and weakened immune system) were provided by the consumption of iodized salt [111]. But, the effects of excessive salt consumption led researchers to find an alternative. Currently, most developed countries use dairy products as the main source of iodine needed by the body [112]. A study in 2011 showed that the mammary gland of dairy cow act as a bio-regulator for iodine excretion [28]. Therefore, significant amounts of iodine consumed by cattle enter milk and can be used as a source of iodine in humans. According to recent research, consuming $250 \mathrm{~mL}$ ( 1.5 glasses) of raw milk per day can meet 29 to $30 \%$ of the iodine needs of adults [34, 113]. According to the results of this review, cow's milk contains high and significant amounts of iodine $(0.284 \mathrm{mg} / \mathrm{L})$ (Table 2), and based on the amount of needs in humans, consumption of $350 \mathrm{~mL}$ of cow's milk per day can provide $66-100 \%$ of the needs of different age groups. Therefore, it can be said that the mentioned positive effects of iodine on the immune system can be significantly observed through milk consumption.

\section{Selenium}

Selenium ( $\mathrm{Se}$ ) as a trace and essential element is especially important for a balanced and effective immune response and ultimately human health. Using a combined transcriptomics and proteomics approach to analyze gene and protein expression in rectal biopsies of healthy individuals, sub-optimal Se status was found to be associated with inhibition of $\mathrm{NF \kappa B}$, IL-1 $\beta$, IL- 6 , and TNF- $\alpha$ signaling and downregulation of immune and inflammatory response pathways [114]. The results of a study showed that serum selenium levels in surviving patients with COVID-19 were significantly higher than in patients who died with COVID-19 [115]. Measurement of cytokines in combination with the genomic approach in mice showed that usage of Se deficiency diet increased the activity of IFN- $\gamma$ and IL- 6 pathways and also increased IL-6 levels [116]. In one study, the use of dietary supplements containing selenium ( $200 \mu \mathrm{g} /$ day for 8 weeks) increased the cytotoxicity of $\mathrm{CD} 8^{+} \mathrm{T}$ cells by increasing the number of cells in the human peripheral blood lymphocyte population [117]. Based on the results of the same study, selenium supplementation also increased the lytic activity of NK cells from human peripheral blood lymphocytes. Therefore, selenium supplementation may increase the function of cytotoxic cells affecting COVID-19 [117]. A study shows that the situation Se with the result of illness COVID-19 has been associated [118] and, therefore, recommended that the $\mathrm{Se}$ is an important factor that should be considered in determining the outcome of infection with SARS-CoV2 be considered (especially in populations where Se consumption is low). According to the results of one experiment, serum levels of antibodies such as immunoglobulin $\mathrm{M}(\operatorname{IgM}), \operatorname{IgG1}$, IgG2a, IgG2b, and IgG3 were lower in selenoprotein deficient mice than in control mice [119]. Selenium deficiency increased the ratio of thromboxane A2 to prostacyclin I 2 in rats [120], inducing vasoconstriction and blood coagulation [121]. The results of studies show that blood coagulation disorders leading to the formation of micro-clots are a significant cause of death in patients with COVID-19 [122, 123]. Therefore, according to the findings, selenium deficiency may be a risk factor for COVID-19 mortality. As you can see in Table 2, cow's milk contains significant amounts of selenium $(0.028 \mathrm{mg} / \mathrm{L})$ relative to human needs. Based on this, consuming $350 \mathrm{~mL}$ of cow's milk per day provides about $29-57 \%$ of the needs of different age groups. Finally, it can be said that the positive and significant effects of selenium on the immune system also can be observed through the consumption of cow's milk (Fig. 2).

\section{Bioactive Peptides in Cow's Milk and Immune System}

Cow's milk is considered an excellent source of proteins with high biological value, which is characterized by its well-balanced amino acid profile and extremely high digestibility [124]. Apart from their obvious nutritive value, milk proteins and products of their degradation (peptides) exert a wide range of biological functions [125, 126]. Milk proteins fall into three categories: caseins, whey proteins, and milk fat globule membrane (MFGM) proteins [127]. Caseins, mainly $\alpha$ s-casein ( $\alpha$ s 1 and $\alpha \mathrm{s} 2), \beta$-casein, and $\kappa$-casein, represent about $78 \%$ of the proteins in bovine milk [128]. Whey proteins such as $\beta$-lactoglobulin, $\alpha$-lactalbumin, lactoferrin, immunoglobulins, serum albumin, glycomacropeptides, enzymes, and growth factors represent another $18 \%$ [129] while proteins from the MFGM represent less than 4\% (Table 3) [130]. Immunomodulatory milk peptides affect both the immune 


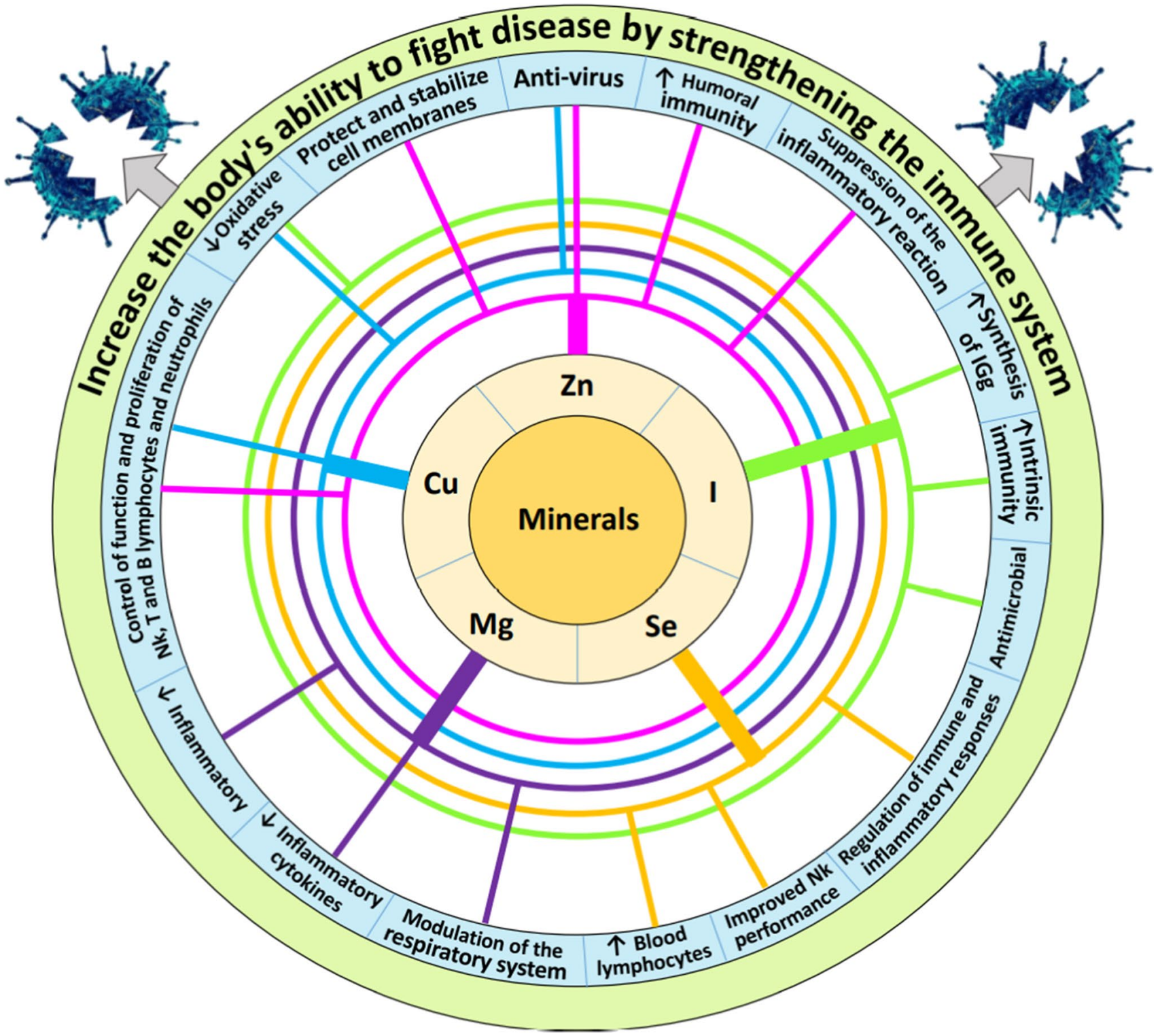

Fig. 2 Important effects of minerals on strengthening the immune system and resistance to pathogens

system and cell proliferation responses. $\beta$-Casokinins inhibit angiotensin-converting enzymes (ACE) that are responsible for inactivating bradykinin, a hormone with immune-enhancing effects [131]. Therefore, this series of events indirectly leads to an overall immuno-stimulatory response in the body. It has been shown that lactoferricin B, obtained by hydrolysis of lactoferrin with pepsin, may promote the phagocytic activity of human neutrophils via dual mechanisms that may involve direct binding to the neutrophil and opsonin-like activity [132]. Bioactive peptides are inactive within the native protein in cow's milk and are activated by (1) proteases present in milk, (2) digestive enzymes and enzymes produced by the gut microbiota, and (3) enzymes secreted by microorganisms (i.e., starter cultures) and/or purified enzymes added to the milk during milk processing [133]. Bioactive peptides from milk are commonly used in the formulation of functional foods, nutraceuticals, and natural medicines because of their many health benefits [134]. For example, small peptides, corresponding to the $\mathrm{N}$-terminal end of bovine $\alpha$-LA (dipeptide) and $\kappa-\mathrm{CN}$ (tripeptide), significantly increased the proliferation of human peripheral blood lymphocytes [135]. According to the report, milk bioactive peptides such as $\beta$-caseokines, $\beta$-casomorphine, and lactoferrin B are able to stimulate the immune response in the body [131]. These bioactive peptides regulate autoimmune inflammatory processes in the body and are useful in protecting the body against infections caused by bacteria, viruses, and parasites [136]. For example, casein-derived peptides have been reported to stimulate 
Table 3 Fractions of milk protein (g/L) of cow's milk [3]

\begin{tabular}{ll}
\hline Protein & Cow \\
\hline Total casein & \\
$\alpha$ s1-Casein & $8-10.7$ \\
$\alpha$ s-Casein & $2.8-3.4$ \\
$\beta$-Casein & $8.6-9.3$ \\
$\kappa$-Casein & $2.3-3.3$ \\
$\gamma$-Casein & 0.8 \\
Casein micelle (nm) & $150-182$ \\
Total whey proteins & \\
$\beta$-Lactoglobulin & $3.2-3.3$ \\
$\alpha$-Lactalbumin & $1.2-1.3$ \\
Serum albumin & $0.3-0.4$ \\
Proteose peptone & $0.8-1.2$ \\
Lactoferrin & $0.02-0.5$ \\
Lysozyme & $(70-600) \times 10^{-6}$ \\
\hline
\end{tabular}

the proliferation of human lymphocytes and the phagocytic activity of macrophages [137]. Lactoferrin also inhibits granulopoiesis and upregulates the activity of natural killer cells [138]. Controlled studies in infants have shown that milk compounds such as milk fat globule membrane, lactoferrin, and $\mathrm{IgG}$ colostrum reduce respiratory infections in them [39]. Valine-proline-proline (VPP) is a milk-derived bioactive peptide that reduces the attachment of monocytes to inflamed endothelium as well as inflammation and prevents primary arteriosclerosis [139]. Recently, a study was conducted on the effect of bioactive peptides on COVID-19; the results of this study show that bioactive peptides with unique amino acid sequences can mitigate such targets including type II transmembrane serine proteases (TMPRSS2) inhibition, furin cleavage, and renin-angiotensin-aldosterone system (RAAS) members [140]. According to the findings of this study, based on structure-function analysis, multiple bioactive peptides present potency to neutralize the virus. In this study, bioactive peptides were also introduced as an effective factor against SARS-CoV-2 infection due to their potential activity [140]. Finally, based on the results reported from various studies, it can be said that cow's milk contains significant amounts of bioactive peptides that can be very beneficial for the proper functioning of the immune system. Since strengthening the immune system against the COVID-19 is the first and most important issue, so the use of cow's milk, which contains bioactive peptides, can provide beneficial effects in this regard.

\section{Conclusion}

The results of the review in this study show that micronutrients such as vitamins D, E, B, C, and A as well as minerals $\mathrm{Zn}, \mathrm{Cu}$, $\mathrm{Mg}$, I, and Se and bioactive peptides, each can have positive and significant effects on strengthening the immune system and general health in humans. Among the nutrients mentioned, vitamins $\mathrm{B}_{3}, \mathrm{~B}_{6}, \mathrm{~B}_{9}, \mathrm{E}$, and $\mathrm{C}$ as well as $\mathrm{Cu}$ provided a very small percentage of human needs through the consumption of cow's milk. But, the rest of the metabolites provided by the consumption of cow's milk provided a high and significant percentage of the needs. Finally, with a comprehensive look at all the components of milk and considering it as a complex, it can be claimed that consuming $350 \mathrm{~mL}$ of milk per day/person (but not in people with lactose intolerance) can have significant effects on strengthening the immune system and fighting viral disease, especially COVID-19.

Author Contribution M.R. Rezaei Ahvanooei contributed to the design, acquisition of data, data analysis, and writing of the manuscript. M.A. Norouzian contributed to the design of the study and writing, reading, and final approval of the manuscript. P. Vahmani contributed to reading, revising, and final approval of the manuscript.

\section{Declarations}

Ethics Approval Not applicable.

Competing Interests The authors declare no competing interests.

\section{References}

1. Bahrami A, Arabestani MR, Taheri M, et al. (2021) Exploring the role of heavy metals and their derivatives on the pathophysiology of COVID-19. Biological Trace Element Research: 1-12.

2. Taheri M, Bahrami A, Habibi P et al (2021) A review on the serum electrolytes and trace elements role in the pathophysiology of COVID-19. Biol Trace Elem Res 199:2475-2481

3. Vargas-Bello-Pérez E, Márquez-Hernández RI, HernándezCastellano LE (2019) Bioactive peptides from milk: animal determinants and their implications in human health. J Dairy Res 86:136-144

4. Foroutan A, Guo AC, Vazquez-Fresno R et al (2019) Chemical composition of commercial cow's milk. J Agric Food Chem 67:4897-4914

5. Rodrı,'guez ER,'guez, et al. (2001) Mineral concentrations in cow's milk from the Canary Island. J Food Composit Anal 14: 419-430.

6. Grant WB, Lahore H, McDonnell SL et al (2020) Evidence that vitamin D supplementation could reduce risk of influenza and COVID-19 infections and deaths. Nutrients 12:988

7. Dankers W, Colin EM, van Hamburg JP et al (2017) Vitamin D in autoimmunity: molecular mechanisms and therapeutic potential. Front Immunol 7:697

8. Bouillon R, Marcocci C, Carmeliet G et al (2019) Skeletal and extraskeletal actions of vitamin D: current evidence and outstanding questions. Endocr Rev 40:1109-1151

9. Martineau AR, Jolliffe DA, Hooper RL, et al. (2017) Vitamin D supplementation to prevent acute respiratory tract infections: systematic review and meta-analysis of individual participant data. Br Med J 356.

10. Wang T-T, Dabbas B, Laperriere D et al (2010) Direct and indirect induction by 1,25 -dihydroxyvitamin $\mathrm{D}_{3}$ of the NOD2/ 
CARD15-defensin $\beta 2$ innate immune pathway defective in Crohn disease. J Biol Chem 285:2227-2231

11. Gombart AF, Borregaard N, Koeffler HP (2005) Human cathelicidin antimicrobial peptide (CAMP) gene is a direct target of the vitamin D receptor and is strongly up-regulated in myeloid cells by 1, 25-dihydroxyvitamin D3. FASEB J 19:1067-1077

12. Milani GP, Macchi M, Guz-Mark A (2021) Vitamin C in the treatment of COVID-19. Nutrients 13:1172

13. Cerullo G, Negro M, Parimbelli M et al (2020) The long history of vitamin C: from prevention of the common cold to potential aid in the treatment of COVID-19. Front Immunol 11:2636

14. Carr AC, Maggini S (2017) Vitamin C and immune function. Nutrients 9:1211

15. Lee GY, Han SN (2018) The role of vitamin E in immunity. Nutrients 10:1614

16. Traber MG, Atkinson J (2007) Vitamin E, antioxidant and nothing more. Free Radical Biol Med 43:4-15

17. Mikkelsen K, Apostolopoulos V (2019) Vitamin $B_{1}, B_{2}, B_{3}, B_{5}$, and $\mathrm{B}_{6}$ and the immune system. Springer, Nutrition and immunity, pp 115-125

18. Shakoor H, Feehan J, Mikkelsen K et al (2021) Be well: a potential role for vitamin B in COVID-19. Maturitas 144:108-111

19. Huang Z, Liu Y, Qi G et al (2018) Role of vitamin A in the immune system. J Clin Med 7:258

20. Ibs K-H, Rink L (2003) Zinc-altered immune function. J Nutr 133:1452S-1456S

21. Novick S, Godfrey J, Godfrey N et al (1996) How does zinc modify the common cold? Clinical observations and implications regarding mechanisms of action. Med Hypotheses 46:295-302

22. Pasternak C (1987) A novel form of host defence: membrane protection by $\mathrm{Ca}^{2+}$ and $\mathrm{Zn}^{2+}$. Biosci Rep 7:81-91

23. Warnes SL, Little ZR, Keevil CW (2015) Human coronavirus $229 \mathrm{E}$ remains infectious on common touch surface materials. MBio 6.

24. Noyce J, Michels H, Keevil C (2007) Inactivation of influenza A virus on copper versus stainless steel surfaces. Appl Environ Microbiol 73:2748-2750

25. Popkin BM, Adair LS, Ng SW (2012) Global nutrition transition and the pandemic of obesity in developing countries. Nutr Rev 70:3-21

26. Sugimoto J, Romani AM, Valentin-Torres AM et al (2012) Magnesium decreases inflammatory cytokine production: a novel innate immunomodulatory mechanism. J Immunol 188:6338-6346

27. Kutter D, Devaquet P, Vanderstocken G et al (2000) Consequences of total and subtotal myeloperoxidase deficiency: risk or benefit? Acta Haematol 104:10-15

28. Norouzian M (2011) Iodine in raw and pasteurized milk of dairy cows fed different amounts of potassium iodide. Biol Trace Elem Res 139:160-167

29. Kelly FC (1961) Iodine in medicine and pharmacy since its discovery-1811-1961. SAGE Publications.

30. Venturi S, Venturi M (2007) Evolution of dietary antioxidants: role of iodine. Tutto Sulla Nutrizione: 1-25.

31. Calder PC, Carr AC, Gombart AF et al (2020) Optimal nutritional status for a well-functioning immune system is an important factor to protect against viral infections. Nutrients 12:1181

32. Fox PF, McSweeney PL, Paul L. (1998) Dairy chemistry and biochemistry. Springer

33. Organization WH (2004) Vitamin and mineral requirements in human nutrition: World Health Organization.

34. Ahvanooei MR, Norouzian M, Hedayati M et al (2021) Effect of potassium iodide supplementation and teat-dipping on iodine status in dairy cows and milk iodine levels. Domestic Anim Endocrinol 74:106504
35. Brighenti S, Bergman P, Martineau AR (2018) Vitamin D and tuberculosis: where next? J Intern Med 284:145-162

36. Forrest KY, Stuhldreher WL (2011) Prevalence and correlates of vitamin D deficiency in US adults. Nutr Res 31:48-54

37. Zemb P, Bergman P, Camargo CA et al (2020) Vitamin D deficiency and the COVID-19 pandemic. J Glob Antimicrob Resist $22: 133-134$

38. Ali N (2020) Role of vitamin D in preventing of COVID-19 infection, progression and severity. Journal of infection and public health.

39. Perdijk O, van Splunter M, Savelkoul HF et al (2018) Cow's milk and immune function in the respiratory tract: Potential mechanisms. Front Immunol 9:143

40. van Neerven RJ, Knol EF, Heck JM et al (2012) Which factors in raw cow's milk contribute to protection against allergies? J Allergy Clin Immunol 130:853-858

41. Gombart AF, Pierre A, Maggini S (2020) A review of micronutrients and the immune system-working in harmony to reduce the risk of infection. Nutrients 12:236

42. Balla M, Merugu GP, Konala VM et al (2020) Back to basics: review on vitamin $D$ and respiratory viral infections including COVID-19. J Community Hosp Intern Med Perspect 10:529-536

43. Linster CL, Van Schaftingen E (2007) Vitamin C. FEBS J 274:1-22

44. Manning J, Mitchell B, Appadurai DA et al (2013) Vitamin $\mathrm{C}$ promotes maturation of T-cells. Antioxid Redox Signal 19:2054-2067

45. Hemilä H, Chalker E (2013) Vitamin C for preventing and treating the common cold. Cochrane database of systematic reviews.

46. Carr AC, Rosengrave PC, Bayer S et al (2017) Hypovitaminosis $\mathrm{C}$ and vitamin $\mathrm{C}$ deficiency in critically ill patients despite recommended enteral and parenteral intakes. Crit Care 21:1-10

47. Earar K, Arbune M, Dorobat $\mathrm{C}$ et al (2020) Biochemical effects and therapeutic application of vitamin C (C6H8O6) on COVID19 infection. Rev Chim 71:473-478

48. Hemilä H, Chalker E (2019) Vitamin C can shorten the length of stay in the ICU: a meta-analysis. Nutrients 11:708

49. Colunga Biancatelli RML, Berrill M, Marik PE (2020) The antiviral properties of vitamin C. Expert Rev Anti Infect Ther 18:99-101

50. Boretti A, Banik BK (2020) Intravenous vitamin C for reduction of cytokines storm in acute respiratory distress syndrome. PharmaNutrition: 100190.

51. Vissers MC, Wilkie RP (2007) Ascorbate deficiency results in impaired neutrophil apoptosis and clearance and is associated with up-regulation of hypoxia-inducible factor $1 \alpha$. J Leukoc Biol 81:1236-1244

52. Camarena V, Wang G (2016) The epigenetic role of vitamin C in health and disease. Cell Mol Life Sci 73:1645-1658

53. Meydani SN, Leka LS, Fine BC et al (2004) Vitamin E and respiratory tract infections in elderly nursing home residents: a randomized controlled trial. JAMA 292:828-836

54. De la Fuente M, Hernanz A, Guayerbas N et al (2008) Vitamin $\mathrm{E}$ ingestion improves several immune functions in elderly men and women. Free Radical Res 42:272-280

55. Spinas E, Saggini A, Kritas S et al (2015) Crosstalk between vitamin B and immunity. J Biol Regul Homeost Agents 29:283-288

56. Neri M, Cantatore $S$, Pomara $C$ et al (2011) Immunohistochemical expression of proinflammatory cytokines IL- $1 \beta$, IL- 6 , TNF- $\alpha$ and involvement of COX-2, quantitatively confirmed by Western blot analysis, in Wernicke's encephalopathy. Pathol Res Pract 207:652-658

57. Ragan I, Hartson L, Pidcoke H et al (2020) Pathogen reduction of SARS-CoV-2 virus in plasma and whole blood using riboflavin and UV light. Plos one 15:e233947 
58. Zhou E, Li Y, Yao M et al (2014) Niacin attenuates the production of pro-inflammatory cytokines in LPS-induced mouse alveolar macrophages by HCA2 dependent mechanisms. Int Immunopharmacol 23:121-126

59. Liu B, Li M, Zhou Z, et al. (2020) Can we use interleukin-6 (IL6) blockade for coronavirus disease 2019 (COVID-19)-induced cytokine release syndrome (CRS)? J Autoimmun. 102452.

60. Boergeling Y, Ludwig S (2017) Targeting a metabolic pathway to fight the flu. FEBS J 284:218-221

61. Digby JE, Martinez F, Jefferson A et al (2012) Anti-inflammatory effects of nicotinic acid in human monocytes are mediated by GPR109A dependent mechanisms. Arterioscler Thromb Vasc Biol 32:669-676

62. Zhang L, Liu Y (2020) Potential interventions for novel coronavirus in China: a systematic review. J Med Virol 92:479-490

63. Mehmel M, Jovanović N, Spitz U (2020) Nicotinamide riboside - the current State of research and therapeutic uses. Nutrients 12:1616

64. Desbarats J (2020) Pyridoxal 5'-phosphate to mitigate immune dysregulation and coagulopathy in COVID-19.

65. Rodriguez-Melendez R, Zempleni J (2003) Regulation of gene

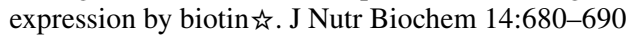

66. Sheybani Z, Dokoohaki MH, Negahdaripour M, et al. (2020) The role of folic acid in the management of respiratory disease caused by COVID-19.

67. Serseg T, Benarous K, Yousfi M (2020) Hispidin and lepidine $\mathrm{E}$ : two natural compounds and folic acid as potential inhibitors of 2019-novel coronavirus main protease (2019-nCoVMpro), molecular docking and SAR study. arXiv preprint arXiv:200408920.

68. Kumar V, Kancharla S, Jena MK (2021) In silico virtual screening-based study of nutraceuticals predicts the therapeutic potentials of folic acid and its derivatives against COVID-19. Virusdisease: $1-9$.

69. Wolffenbuttel BH, Wouters HJ, Heiner-Fokkema MR et al (2019) The many faces of cobalamin (vitamin B12) deficiency. Mayo clinic proceedings: innovations, quality \& outcomes 3:200-214

70. Kandeel M, Al-Nazawi M (2020) Virtual screening and repurposing of FDA approved drugs against COVID-19 main protease. Life Sci 251:117627

71. dos Santos LMJ (2020) Can vitamin B12 be an adjuvant to COVID-19 treatment? GSC Biol Pharm Sci 11:001-005

72. Jørgensen MJ, Hein-Kristensen L, Hempel C et al (2011) The effect of vitamin A supplementation and diphtheria-tetanus-pertussis vaccination on parasitaemia in an experimental murine malaria model. Scand J Infect Dis 43:296-303

73. Jayawardena R, Sooriyaarachchi P, Chourdakis M et al (2020) Enhancing immunity in viral infections, with special emphasis on COVID-19: a review. Diabetes Metab Syndr 14:367-382

74. Patel N, Penkert RR, Jones BG et al (2019) Baseline serum vitamin $A$ and $D$ levels determine benefit of oral vitamin $A \& D$ supplements to humoral immune responses following pediatric influenza vaccination. Viruses 11:907

75. Paiva S, Godoy Id, Vannucchi $\mathrm{H}$ et al (1996) Assessment of vitamin A status in chronic obstructive pulmonary disease patients and healthy smokers. Am J Clin Nutr 64:928-934

76. Brown CC, Noelle RJ (2015) Seeing through the dark: new insights into the immune regulatory functions of vitamin A. Eur J Immunol 45:1287-1295

77. Schwartz E, Zelig R, Parker A et al (2017) Vitamin A supplementation for the prevention of bronchopulmonary dysplasia in preterm infants: an update. Nutr Clin Pract 32:346-353

78. Araki S, Kato S, Namba F et al (2018) Vitamin A to prevent bronchopulmonary dysplasia in extremely low birth weight infants: a systematic review and meta-analysis. PloS One 13:e0207730
79 Sarohan AR (2020) COVID-19: endogenous retinoic acid theory and retinoic acid depletion syndrome. Medical Hypotheses 144:110250

80. Trumbo P, Yates AA, Schlicker S et al (2001) Dietary reference intakes: vitamin A, vitamin $\mathrm{K}$, arsenic, boron, chromium, copper, iodine, iron, manganese, molybdenum, nickel, silicon, vanadium, and zinc. J Am Diet Assoc 101:294-301

81. Caccialanza R, Laviano A, Lobascio F et al (2020) Early nutritional supplementation in non-critically ill patients hospitalized for the 2019 novel coronavirus disease (COVID-19): Rationale and feasibility of a shared pragmatic protocol. Nutrition 74:110835

82. Kumar A, Kubota Y, Chernov M et al (2020) Potential role of zinc supplementation in prophylaxis and treatment of COVID19. Medical hypotheses 144:109848

83. Krenn B, Gaudernak E, Holzer B et al (2009) Antiviral activity of the zinc ionophores pyrithione and hinokitiol against picornavirus infections. J Virol 83:58-64

84. Rahman MT, Idid SZ (2020) Can Zn be a critical element in COVID-19 treatment? Biological Trace Element Research: $1-9$.

85. Novick S, Godfrey J, Pollack R et al (1997) Zinc-induced suppression of inflammation in the respiratory tract, caused by infection with human rhinovirus and other irritants. Med Hypotheses 49:347-357

86. Overbeck S, Rink L, Haase H (2008) Modulating the immune response by oral zinc supplementation: a single approach for multiple diseases. Arch Immunol Ther Exp 56:15-30

87. Te Velthuis AJ, van den Worm SH, Sims AC et al (2010) $\mathrm{Zn}^{2+}$ inhibits coronavirus and arterivirus RNA polymerase activity in vitro and zinc ionophores block the replication of these viruses in cell culture. PLoS Pathogens 6:e1001176

88. Linder MC, Hazegh-Azam M (1996) Copper biochemistry and molecular biology. Am J Clin Nutr 63:797S-811S

89. Raha S, Mallick R, Basak S et al (2020) Is copper beneficial for COVID-19 patients? Medical hypotheses 142:109814

90. Van Doremalen N, Bushmaker T, Morris DH et al (2020) Aerosol and surface stability of SARS-CoV-2 as compared with SARSCoV-1. N Engl J Med 382:1564-1567

91. Aboubakr HA, Sharafeldin TA, Goyal SM (2021) Stability of SARS-CoV-2 and other coronaviruses in the environment and on common touch surfaces and the influence of climatic conditions: a review. Transbound Emerg Dis 68:296-312

92. Fooladi S, Matin S, Mahmoodpoor A (2020) Copper as a potential adjunct therapy for critically ill COVID-19 patients. Clinical nutrition ESPEN 40:90-91

93. Kardos J, Héja L, Simon Á et al (2018) Copper signalling: causes and consequences. Cell Commun Signal 16:1-22

94. Tang C-F, Ding H, Jiao R-Q, et al. (2020) Possibility of magnesium supplementation for supportive treatment in patients with COVID-19. Eur J Pharmacol 173546.

95. De Baaij JH, Hoenderop JG, Bindels RJ (2015) Magnesium in man: implications for health and disease. Physiological reviews.

96. Li X, Hu C, Su F, et al. (2020) Hypokalemia and clinical implications in patients with coronavirus disease 2019 (COVID-19). MedRxiv.

97. Castiglioni S, Cazzaniga A, Locatelli L et al (2017) Burning magnesium, a sparkle in acute inflammation: gleams from experimental models. Magnes Res 30:8-15

98. Stankovic MS, Janjetovic K, Velimirovic M et al (2016) Effects of IL-33/ST2 pathway in acute inflammation on tissue damage, antioxidative parameters, magnesium concentration and cytokines profile. Exp Mol Pathol 101:31-37

99. Iotti S, Wolf F, Mazur A, et al. (2020) The COVID-19 pandemic: is there a role for magnesium? Hypotheses and perspectives. Magnesium Research 1. 
100. Wallace TC (2020) Combating COVID-19 and building immune resilience: a potential role for magnesium nutrition? J Am Coll Nutr 39:685-693

101. Kunachowicz H, Stibilj V, Stoś K et al (2000) Studies on iodine content in daily diets and selected dairy products. Eur Food Res Technol 211:229-233

102. Venturi S, Venturi M (2009) Iodine, thymus, and immunity. Nutrition 25:977-979

103. Derscheid RJ, van Geelen A, Berkebile AR et al (2014) Increased concentration of iodide in airway secretions is associated with reduced respiratory syncytial virus disease severity. Am J Respir Cell Mol Biol 50:389-397

104. Nikam ST (2015) Study of Karpoor ghrita and povidine iodine in sadyo vrana. Int J Ayurvedic Med 6:329-334

105. Allen V, Pond K, Saker K et al (2001) Tasco-Forage: III. Influence of a seaweed extract on performance, monocyte immune cell response, and carcass characteristics in feedlot-finished steers. J Anim Sci 79:1032-1040

106. Saker K, Fike J, Veit $\mathrm{H}$ et al (2004) Brown seaweed-(TascoTM) treated conserved forage enhances antioxidant status and immune function in heat-stressed wether lambs. J Anim Physiol Anim Nutr 88:122-130

107. Weetman A, McGregor A, Campbell H et al (1983) Iodide enhances IgG synthesis by human peripheral blood lymphocytes in vitro. Eur J Endocrinol 103:210-215

108. Bilal MY, Dambaeva S, Kwak-Kim J et al (2017) A role for iodide and thyroglobulin in modulating the function of human immune cells. Front Immunol 8:1573

109. Organization WH (2020) Coronavirus disease 2019. 2020. Availabe online at: https://www.who.int/emergencies/disea ses/novel-coronavirus-2019 (accessed June 18, 2020).

110. Scherbov S, Andruchowitz S, Sanderson W (2018) Aging demographic data sheet 2018.

111. Fund UNCs (2000) Curriculum report card: Unicef.

112. Pearce EN, Pino S, He X et al (2004) Sources of dietary iodine: bread, cows' milk, and infant formula in the Boston area. J Clin Endocrinol Metab 89:3421-3424

113. RezaeiAhvanooei MR, Norouzian MA, Hedayati M (2020) Iodine concentration in Iranian dairy milk products and its contribution to the consumer's iodine intake. Iran J Vet Med 14:159-165

114. Méplan C, Johnson IT, Polley AC et al (2016) Transcriptomics and proteomics show that selenium affects inflammation, cytoskeleton, and cancer pathways in human rectal biopsies. FASEB J 30:2812-2825

115. Moghaddam A, Heller RA, Sun Q et al (2020) Selenium deficiency is associated with mortality risk from COVID-19. Nutrients 12:2098

116. Tsuji PA, Carlson BA, Anderson CB et al (2015) Dietary selenium levels affect selenoprotein expression and support the interferon- $\gamma$ and IL-6 immune response pathways in mice. Nutrients 7:6529-6549

117. Kiremidjian-Schumacher L, Roy M, Wishe HI et al (1994) Supplementation with selenium and human immune cell functions. Biol Trace Elem Res 41:115-127

118. Zhang J, Taylor EW, Bennett K et al (2020) Association between regional selenium status and reported outcome of COVID-19 cases in China. Am J Clin Nutr 111:1297-1299

119. Commans S, Böck A (1999) Selenocysteine inserting tRNAs: an overview. FEMS Microbiol Rev 23:335-351

120. Haberland A, Neubert K, Kruse I et al (2001) Consequences of long-term selenium-deficient diet on the prostacyclin and thromboxane release from rat aorta. Biol Trace Elem Res $81: 71-78$
121. Miller SB, (2006) editor Prostaglandins in health and disease: an overview. Seminars in arthritis and rheumatism; Elsevier.

122. Zhou F, Yu T, Du R et al (2020) Clinical course and risk factors for mortality of adult inpatients with COVID-19 in Wuhan, China: a retrospective cohort study. The Lancet 395:1054-1062

123. Fogarty H, Townsend L, Ni Cheallaigh C et al (2020) COVID19 coagulopathy in Caucasian patients. Br J Haematol 189:1044-1049

124. Szwajkowska M, Wolanciuk A, Barłowska J et al (2011) Bovine milk proteins as the source of bioactive peptides influencing the consumers' immune system-a review. Anim Sci Pap Rep 29:269-280

125. Król J, Brodziak A, Litwińczuk Z et al (2011) Whey protein utilization in health promotion. Żywienie Człowieka i Metabolizm 38:36-45

126. Litwińczuk Z, Król J, Brodziak A et al (2011) Changes of protein content and its fractions in bovine milk from different breeds subject to somatic cell count. J Dairy Sci 94:684-691

127 Hernandez-Castellano LE, Almeida AM, Castro N et al (2014) The colostrum proteome, ruminant nutrition and immunity: a review. Curr Protein Pept Sci 15:64-74

128. Heck J, Schennink A, Van Valenberg H et al (2009) Effects of milk protein variants on the protein composition of bovine milk. J Dairy Sci 92:1192-1202

129. McGregor RA, Poppitt SD (2013) Milk protein for improved metabolic health: a review of the evidence. Nutr Metab 10:1-13

130. Murgiano L, Timperio AM, Zolla L et al (2009) Comparison of milk fat globule membrane (MFGM) proteins of Chianina and Holstein cattle breed milk samples through proteomics methods. Nutrients 1:302-315

131. Clare D, Swaisgood H (2000) Bioactive milk peptides: a prospectus. J Dairy Sci 83:1187-1195

132. Miyauchi H, Hashimoto S-i, Nakajima M et al (1998) Bovine lactoferrin stimulates the phagocytic activity of human neutrophils: identification of its active domain. Cell Immunol 187:34-37

133. Espejo-Carpio FJ, Pérez-Gálvez R, Guadix A, et al. (2018) Artificial neuronal networks (ANN) to model the hydrolysis of goat milk protein by subtilisin and trypsin.

134. Muro Urista C, Álvarez Fernández R, Riera Rodriguez F et al (2011) Production and functionality of active peptides from milk. Food Sci Technol Int 17:293-317

135. Kayser H, Meisel H (1996) Stimulation of human peripheral blood lymphocytes by bioactive peptides derived from bovine milk proteins. FEBS Lett 383:18-20

136. Gauthier SF, Pouliot Y, Saint-Sauveur D (2006) Immunomodulatory peptides obtained by the enzymatic hydrolysis of whey proteins. Int Dairy J 16:1315-1323

137. Korhonen H, Pihlanto A (2007) Technological options for the production of health-promoting proteins and peptides derived from milk and colostrum. Curr Pharm Des 13:829-843

138. Marcone S, Belton O, Fitzgerald DJ (2017) Milk-derived bioactive peptides and their health promoting effects: a potential role in atherosclerosis. Br J Clin Pharmacol 83:152-162

139. Aihara K, Ishii H, Yoshida M (2009) Casein-derived tripeptide, Val-Pro-Pro (VPP), modulates monocyte adhesion to vascular endothelium. J Atheroscler Thromb 16:594-603

140. Bhullar KS, Drews SJ, Wu J (2021) Translating bioactive peptides for COVID-19 therapy. Eur J Pharmacol 890:173661

Publisher's Note Springer Nature remains neutral with regard to jurisdictional claims in published maps and institutional affiliations. 